\title{
A study on students' perceived and preferred teaching styles in Philippine politics
}

\author{
Roger Christopher R. Reyes * \\ Department of Basic Education, University of the East, Caloocan City, Philippines
}

\section{Keywords \\ Philippine politics \\ Teaching styles \\ Thinking styles}

Received: 1 October 2019

Accepted: 4 November 2019

Published: 23 December 2019

\begin{abstract}
This study has three objectives: first, to determine students' thinking styles based on Sternberg's Theory of Mental Self-Government; second, to determine the teaching style used by Philippine politics teachers as perceived by their students; and, third, to ascertain the teaching style students preferred their teachers to use. To achieve the second and third objectives, Grasha's teaching styles were considered in the study. 149 Grade 12 students from the Humanities and Social Sciences (HUMSS) Strand of the University of the East Caloocan served as respondents of the study. Data were gathered through survey questionnaires. Legislative, judicial, external, and multimodal thinkers perceived their teachers as experts, while executive and internal thinkers perceived them as a formal authority. Legislative, external, and multimodal thinkers preferred their teachers to be a formal authority, while internal thinkers preferred facilitators, and executive and judicial thinkers preferred personal models. Valuable insights and suggestions for teachers and students are provided.
\end{abstract}

(C) 2019 The Author(s). Published by TAF Publishing

\section{INTRODUCTION}

Social studies courses-history, geography, civics, culture, and politics, among others-are necessary for the social and academic development of students, as their content is related to and can be used in daily life (Topçu, 2017). These courses aim to raise citizens who value democratic life and contribute to the understanding of the world we live in. As such, they have been incorporated in the curriculum. A specialized subject in the K-12 curriculum, Philippine Politics and Governance includes lessons in Philippine history and fundamental concepts in political science. When social science subjects are well taught by experts in the field, students will turn out better citizens able to manage relevant social issues and find solutions to them (Koko \& Nwiyi, 2007).

Every child is special. So the adage goes. Students differ from each other. They learn in ways that harness their strengths and overcome their weaknesses. What is effective to one may not be effective to others. This is where teach- ing styles and classroom processes come into play (Grasha, 1996).

\section{Objectives of the Study}

This study aimed to determine three things: first, the respondents' thinking styles; second, the teaching style perceived used by their Philippine politics teachers; and third, the teaching style they preferred their teachers to use.

\section{REVIEW OF RELATED LITERATURE Thinking Styles}

There are various ways of governing or managing one's activities. Sternberg and Wagner (1991) proposed the Theory of Mental Self-Government. Here, thinking styles, which are associated to concepts in politics and government, were proposed. A thinking style is a personality attribute for the utilization of abilities. Understanding these thinking styles allows teachers to provide differentiated instruction to students and, in doing so, accommodate students' individual differences (Boonphadung, 2017; Sternberg \& Zhang,

\footnotetext{
* corresponding author: Roger Christopher R. Reyes

†email: archierreyes@yahoo.com
} 
2005). The theory enumerated 13 thinking styles where people can be understood in terms of the functions, forms, levels, scopes, and leanings of government.

First, governments have primary functions: legislative, executive, and judicial. As the legislative branch makes laws, executive branch implements laws, and judicial branch interprets laws, these functions can also be reflected in the types of mental processes and problem-solving skills of individuals. Thus, Legislative thinkers-those who are inclined to create, formulate, and plan ideas and strategies-are creative and like to decide what to do and how to do it rather than to be told; Executive thinkers-those who are inclined to work on tasks that provide structure, procedure, or rules are conforming in the sense that they prefer to be told what to do; and Judicial thinkers-those who are inclined to work on tasks that require evaluation, analysis, comparison and contrast, and judgment of ideas and strategies-are analytical (De Silva, 2016; Gafoor, 2012; Sternberg \& Zhang, 2005). Second, governments come in different forms: monarchic, hierarchic, oligarchic, and anarchic. These forms deal with how students accomplish tasks or goals. Thus, Monarchic thinkers focus on one particular thing at a time until its completion; Hierarchic thinkers come up with a list of priorities and act on them based on their importance; Oligarchic thinkers focus on multiple and competing goals at the same time; and Anarchic thinkers, being flexible and adopting a random approach to things, act on tasks and goals when and where they please. Third, governments function at global and local levels. These levels reflect the nature of ideas involved and one's focus on details. Whereas Global thinkers deal with large and abstract ideas and do not like paying attention to details, Local thinkers deal with specific and concrete details. Fourth, as governments deal with domestic and foreign affairs, internal and external thinkers also deal with them. Thus, Internal thinkers tend to flourish in tasks applying intelligence in isolation from others, as External thinkers flourish in the world of others as well as of oneself. Internal thinkers, typically introverted and uncomfortable in groups, would like to work on their own. External thinkers, typically extroverted and inclined to work in a group, would like to collaborate with others. Finally, governments lean towards a liberal or a conservative approach. Thus, Liberal thinkers are open to change and go beyond the usual rules or procedures, as Conservative thinkers like to minimize change and stick to conventional rules or procedures (Sternberg \& Wagner, 1991; Sternberg \& Zhang, 2005).

\section{Teaching Styles}

Grasha (1996) defined teaching styles as teachers' personal qualities that guide and direct their selection of instructional processes. These are particular patterns of needs, beliefs, and behaviors that teachers display in the classroom. It is said that a good teacher must possess the style that appropriately responds to his students' needs. Equally important, a good teacher must know a variety of styles, employ them, and determine what is appropriate at a given instance (Hill, Tomkinson, Hiley, \& Dobson, 2016). If teachers were to accomplish these, students would experience greater satisfaction and derive a more positive attitude towards the subject (Gafoor, 2012; Suwanwong, 2017). For instance, Nasibi and Kiio (2005) cited teaching styles used in history classes: direct method, discussion, recitation, taking down notes, brainstorming, role playing, dramatizing, group projects, debates, panel group discussion, and field trips. Sosu (2016) observed that history tutors departed from the traditional lecture style that required memorization of facts and events, in favor of an activity and integrative method in learning.

To make the most out of the teaching-learning process, teachers can choose from a wide range of styles. Gafoor (2012) provided a matrix that presented the different teaching styles from different scholars, including Grasha (1994), Grasha (1996) and Sternberg and Wagner (1991), Sternberg and Zhang (2005). For Grasha (1994), Grasha (1996), there are five teaching styles: Expert, Formal Authority, Personal Model, Facilitator, and Delegator. As Expert, the teacher is the transmitter of information. He is the focal point of all activity on account of his detailed knowledge of the subject. As Formal Authority, the teacher sets standards and lays down acceptable rules and procedures. This style highlights the teacher's feedback mechanism. As Personal Model, the teacher teaches by direct example. As such, he shows students how to think and behave. As Facilitator, the teacher guides and directs students by asking questions, exploring options, and suggesting solutions. As Delegator, the teacher develops students' ability to learn autonomously.

Styles can be direct teaching, peer teaching, problem solving, and group approach. In direct teaching, the focus is on the teacher as main source of knowledge: the teacher decides what is to be learned, the teacher evaluates, and the teacher provides feedback. In peer teaching, two students of differing ability levels are paired and provide feedback 
on each other's output based on the criteria given by the teacher. In problem solving, a problem is posed and students use their creativity in responding to it. In group approach, social skills are harnessed alongside acceptance of individual differences (Gafoor, 2012).

Styles can be expressive or instrumental. Expressive teaching style highlights the emotional relationship between the teacher and the students, where the former serves as mentors to the latter. This style involves warmth, sympathy, trust, and confidence from the teacher. Instrumental teaching style, on the other hand, highlights the teacher's roles in assisting students, preparing lessons, and setting up classroom activities (Sosu, 2016). Styles can also be associated to parenting styles. Whereas authoritative teachers apply control reasonably while showing warmth and affection to their students, authoritarian teachers control students excessively and do not express enough love (Göncz, 2017).

\section{METHODOLOGY}

\section{Research Design}

The study adopted a descriptive research design, with a selfreport survey to determine respondents' thinking styles and their preferred teaching styles. This design was also adopted to help the researcher gather personalized statements from respondents after having been required to complete open-ended statements.

\section{Respondents of the Study}

149 Grade 12 HUMSS students of the University of the East Caloocan, with Philippine Politics and Governance as specialized subject for School Year 2019-2020, were the respondents of this study.

\section{Data Collection and Analysis}

Data were gathered through a survey questionnaire designed by the researcher. The questionnaire had three parts: Part 1 gathered respondents' information, Part 2 served as an inventory to determine respondents' thinking styles, and Part 3 comprised of completion statements.

The researcher adopted the items in Part 2 from Sternberg and Wagner (1991) Thinking Styles Inventory. Out of the 13 thinking styles, only 5 were included in the study, namely Legislative, Executive, Judicial, Internal, and External. Respondents were guided in accomplishing the inventory. If their inventory yielded more than thinking style, then they would be considered multimodal. Part 3 required respondents to complete the following statements: "I learn in my Philippine Politics and Governance subject when my teacher..." and "I will appreciate and learn more in my Philippine Politics and Governance subject if my teacher..."
Responses to these statements reflected the teaching styles perceived and preferred, respectively, by students following Grasha (1996) Teaching Styles: Expert, Formal Authority, Personal Model, Facilitator, and Delegator.

Thematic analysis was employed in this study. The researcher coded every data item, searched for themes based on the frequency of responses, and grouped and collated coded data relevant to each theme.

\section{RESULTS AND DISCUSSION \\ Respondents' Thinking Styles}

The most frequent thinking style (46 out of 149 respondents, or 31\%) was External. These students prefer working in groups to working individually (Sternberg \& Zhang, 2005). Their main characteristics include being peopleoriented, outgoing, socially sensitive, and interpersonally aware. When a task is given to them, they involve themselves with other people (Sternberg \& Wagner, 1991). According to respondents, the relevance of the subject cannot be denied since it deals with issues that affect and matter to them. As members of the society, they must be mindful of these things.

$R$ 55: The room is lively and everyone has or is given the chance to share ideas with interesting illustrations that are relatable.

R 111: [My teacher] discusses matters that capture my attention. I got to learn things concerning how our government works and that widens my knowledge.

The second most frequent thinking style (42 respondents, or 28\%) was Executive. These students are conforming. They are implementers. They like to follow rules and figure out which of the existing ways should be used in getting things done (Sternberg \& Wagner, 1991). When a task is given, they prefer to be told what to do and, thereafter, will give their best shot at doing it well (Sternberg \& Zhang, 2005). According to respondents, they enjoyed learning about politics because of their teachers, who discussed things from roots to ends and provided discussions to which they could relate.

R 60: My subject teacher gives all the definitions and terms and clearly explains to the class the different topics and subtopics.

R 16: My teacher is very knowledgeable about the subject and he definitely shares all his knowledge to us. He is able to successfully teach us information that is relevant to the subject.

The third most frequent thinking style (35 respondents, or $23 \%)$ was Legislative. These students are creators or formulators of ideas and strategies. They like to create their 
own rules and enjoy doing things their own way (Sternberg \& Wagner, 1991). When a task is given to them, instead of being told or instructed, they would like to decide what to do and how to do it (Sternberg \& Zhang, 2005). According to respondents, the subject is interesting and mindstimulating. The subject prompts them to read and make sense of the assigned materials by asking questions which are appropriately addressed by their teachers.

R 62: I listen, write the important details, and study on my own.

R 116: I listen and do my own thing when listening to discussions. I take down notes.

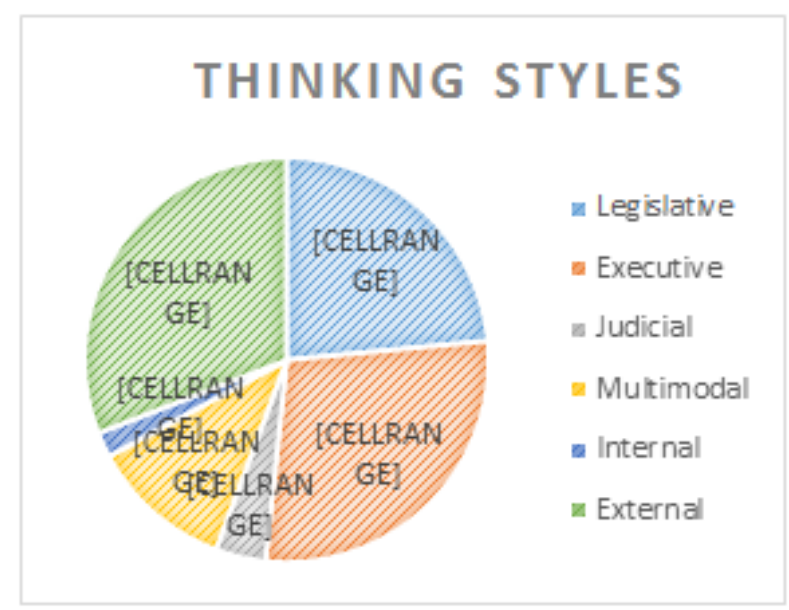

FIGURE 1. Thinking styles of respondents

6 respondents (4\%) were Judicial thinkers, and only 3 (2\%) were Internal thinkers. 17 respondents $(11 \%)$ were consid- ered multimodal.

\section{Respondents' Perceived Teaching Style}

Figure 1 shows that the three most frequent teaching styles perceived to be used by Philippine politics teachers are Expert (48 out of 149 respondents, or 32\%), Formal Authority (46 respondents, or 31\%), and Personal Model (33 respondents, or 22\%). Expert registered as the most frequent perceived teaching style among Legislative, Judicial, External, and multimodal thinkers, as Formal Authority did among Executive and Internal thinkers.

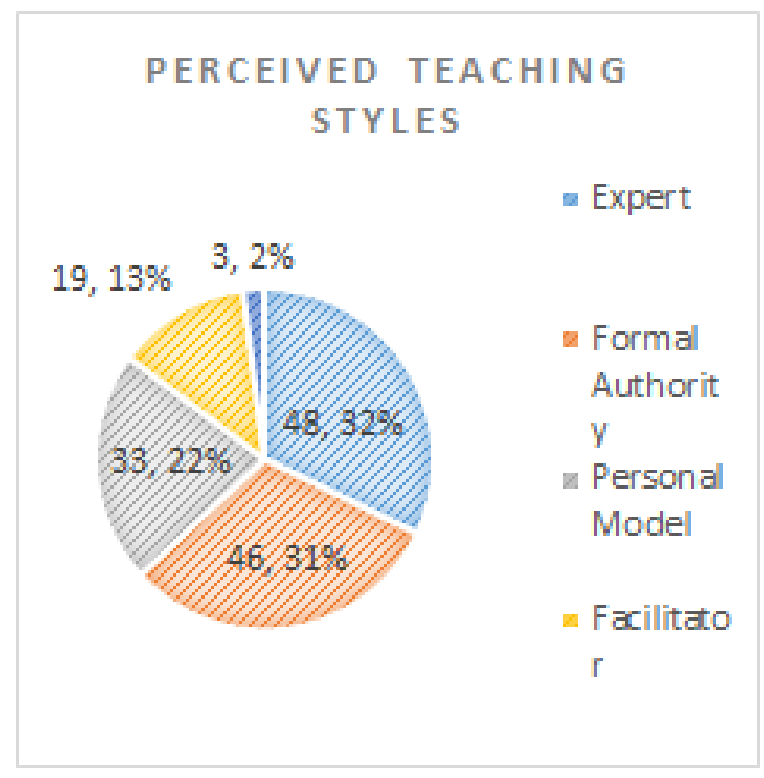

FIGURE 2. Perceived teaching styles

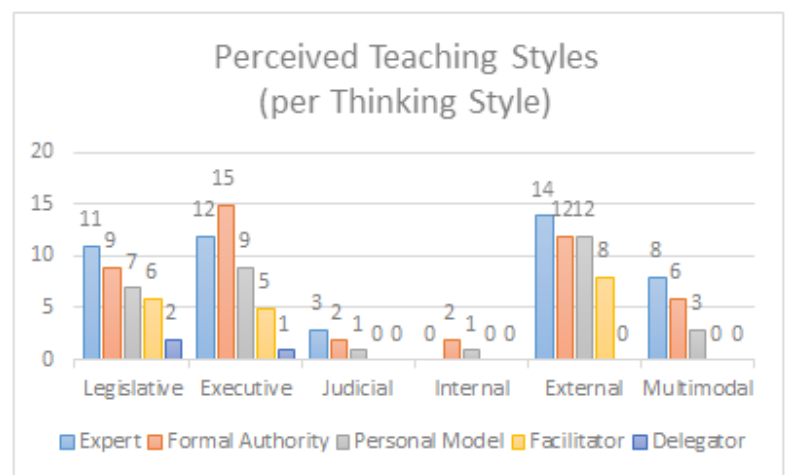

FIGURE 3. Perceived teaching styles per thinking style

Almost a third of the respondents viewed their teachers as Expert. For these respondents, their teachers had mastery of the subject, as manifested in their ability to define, explain, and process concepts well in a language and manner easily understood by students. They taught students information and lessons beyond what the book could offer. They dissected lessons by expounding new concepts and provid- ing illustrative examples.

R 37: I learn in my Philippine Politics and Governance subject when my teacher is teaching the lesson clearly and creatively, is knowledgeable about the subject, and can answer my questions.

R 49: My teacher simplifies the topic, gives examples to better understand the topic, and tells jokes related to it. 
R 44: My teacher elaborates ideas and enlightens us about different things related to our subject.

R 64: My teacher shares the ideas that we need to know thoroughly and our teacher also dissects ideas to its roots. Respondents who perceived their teachers as Formal Authority cited the role played by the latter in making sure they learned every meeting. According to them, their teachers got their attention before discussing lessons and used different visual aids and graphic organizers to facilitate easier learning. They even repeated difficult lessons and provided feedback. They solicited students' insights and accommodated questions.

R 19: I learn in my Philippine Politics and Governance subject when my teacher repeats a concept that has been discussed and tries his/her best to make us understand through practical examples.

R 63: My teacher entertains the questions of other students. Respondents who perceived their teachers as Personal Model pointed out the latter's provision of illustrative examples as a way of explaining concepts. According to them, their teachers connected the lessons to current sociopolitical situations and issues as seen in the news and social media. Graphic organizers and different group activities were effectively assigned to show how concepts are applied or manifested in real life.

R 23: I learn in my Philippine Politics and Governance subject when my teacher draws concepts on the board as symbols.

$\mathrm{R}$ 55: My teacher is demonstrating or illustrating the ideas and concepts of the lesson by doing an act or skit, then re- lates it to the lesson for further understanding.

\section{Respondents' Preferred Teaching Style}

The three most frequent teaching styles respondents preferred their Philippine politics teachers to use, as shown in Figure 4, are as follows: Formal Authority ( 49 out of 149 respondents, or $33 \%$ ), Facilitator (31 respondents, or $21 \%$ ), and Expert (29 respondents, or 19\%). Formal Authority registered as the most frequent preferred teaching style among Legislative, External, and multimodal thinkers, as Facilitator did among Internal thinkers. Though only fourth, Personal Model was the most frequent preferred teaching style among Executive and Judicial thinkers.

\section{PREFERRED TEACHING STYLES}

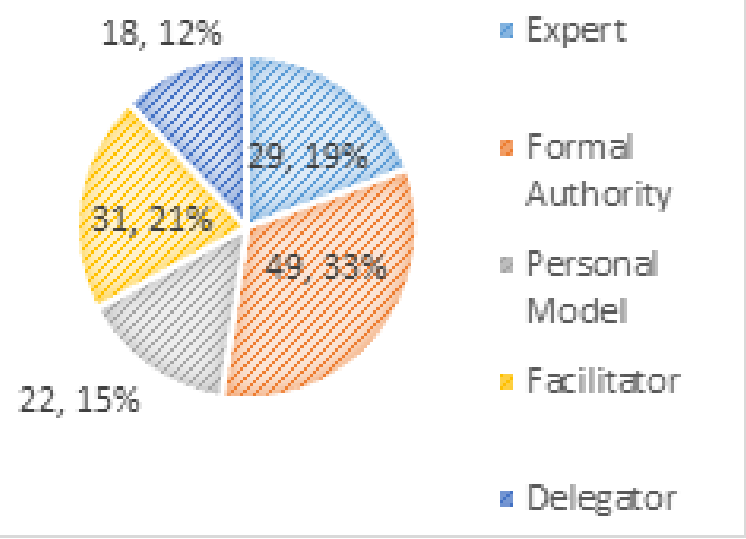

FIGURE 4. Preferred teaching styles

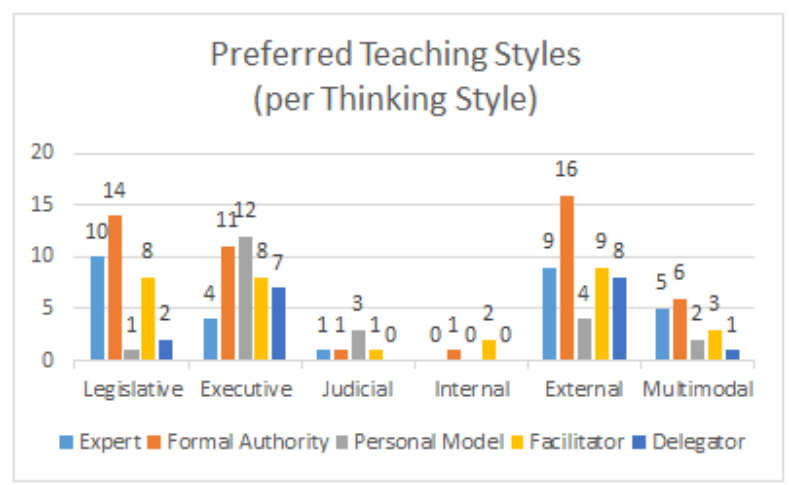

FIGURE 5. Preferred teaching styles per thinking style

One-third of the respondents preferred their teachers to use Formal Authority. Respondents highlighted the personality their teachers must possess. How their teachers dealt with them, is crucial. Thus, respondents believed that teachers should continue what they are doing in order to maintain effectiveness: being dedicated on what they do, being optimistic and appreciative of students' efforts, being transparent and objective, and being a source of inspiration, among others. Likewise, they believed that teachers must not be strict and must have consideration and patience. 
R 42: I will appreciate and learn more in my Philippine Politics and Governance subject if my teacher will discuss topics slowly and not give us a pile of reading materials in one discussion for the next meeting. It's okay but it can be a hassle when we are also bombarded with activities in other subjects.

R 26: I will appreciate and learn more in my Philippine Politics and Governance subject if my teacher helps us to easily catch up with the lesson and gives us worksheets to answer. R 123: I will appreciate and learn more in my Philippine Politics and Governance subject if my teacher is not too focused on seeing what's wrong with us. When he/she gives us consideration, we tend to like the subject and it makes us listen well.

Respondents who preferred their teachers to use Facilitator mentioned ways of putting them directly into the lessons. They believed that when they participated in recitation or group activities, their minds could process information better. If teachers were to be facilitators, then they would conveniently devise an easy method that will allow students to understand and make sense of the lessons and the subject as a whole.

R 63: I will appreciate and learn more in my Philippine Politics and Governance subject if my teacher lets opposing ideas take shape and have a debate.

R 71: I will appreciate and learn more in my Philippine Politics and Governance subject if my teacher is just like a friend telling stories about society. I think I will learn more if he/she is not that strict and encourages everyone to speak up their minds.

Respondents who preferred their teachers to use Expert highlighted the role of the teacher as the source of information in the classroom. Respondents believed that teachers should explain the concepts and terminologies comprehensively and, at the same time, allow them to utilize information and express their own opinions. They reiterated that, in explaining technical words, teachers should speak in the vernacular.

R 1: I will appreciate and learn more in my Philippine Politics and Governance subject if my teacher will do the talking mostly because sometimes we, students, get a lot of pressure and end up getting anxious about the subject.

R 70: I will appreciate and learn more in my Philippine Politics and Governance subject if my teacher will explain and teach us until we understand the topic before proceeding to the next one.

\section{CONCLUSION}

Data gathered showed respondents learned in their Philippine politics subject in different ways. Most of the respon-

ISSN: 2414-3111

DOI: $10.20474 /$ jahss-5.6.1 dents found their teachers' method and strategies in class as the main reason they learned in the subject. As the teachers' role proved to be crucial, respondents provided testimonies of them employing a variety of styles: from the traditional direct method to the group work, from the recitation of cases and political law doctrines to the giving of reallife examples. Using different teaching styles appropriate to the students' learning and/or thinking styles is, indeed, crucial in making sure that the subject's desired learning outcomes are achieved (Koko \& Nwiyi, 2007; Sarabdeen, 2013). Most of the respondents preferred their teachers to be formal authorities and facilitators. Not only do they want to explore concepts using a student-centered approach, but they also want to be informed of their teachers' expectations through constructive feedback (Grasha, 1996). Responses showed that establishing good relationships with their teachers based on respect and rapport, is helpful in maintaining the discipline in the class. Thus, the basis of such discipline is not the authority out of fear among students, but the authority out of respect and trust (Khandaghi \& Farasat, 2011).

\section{LIMITATIONS AND RECOMMENDATIONS}

This study, like any other research, has potential for improvement and it must be extended with other subjects and student sample. Based on the data gathered, the researcher would like to offer the following recommendations. First, social science teachers should continuously equip themselves with different teaching styles by reviewing the available literature on the matter, attending seminars/workshops which deal with teaching methods and strategies, and collaborating with other teachers/experts by sharing best practices. It is imperative that teachers understand the importance of teaching styles, apply them when appropriate, and match them with students' learning styles. Second, teachers must always be willing to diversify their use of teaching styles. On account of students' different thinking and learning styles, differentiated instruction must be employed. As some students favor direct method in delivering social science courses, others would prefer a studentcentered approach. As others prefer working alone, others would opt to cooperate. Finally, this study can further be enhanced by broadening the scope of respondents, such that students in other schools, whether private or public, will be asked to participate in the survey. It is also possible that other social science subjects taken by students are included in the study. 


\section{REFERENCES}

Boonphadung, S. (2017). Critical thinking development: A comparison between the efficiency of mixed technique and a series of mini-lecture, KWL/T-P-S and presentation. Journal of Advances in Humanities and Social Sciences, 3(2), 95-104. doi:https://doi.org/10.20474/jahss-3.2.3

De Silva, D. K. (2016). Developing service-oriented government agencies: Observations on the divisional secretariats in Galle, Sri Lanka. International Journal of Humanities, Arts and Social Sciences, 2(5), 165-171. doi:https://doi.org/ $10.20469 /$ ijhss.2.20002-5

Gafoor, K. A. (2012). Teaching style: A conceptual overview. London, UK: Sage Publications.

Göncz, L. (2017). Teacher personality: A review of psychological research and guidelines for a more comprehensive theory in educational psychology. Open Review of Educational Research, 4(1), 75-95. doi:https://doi.org/10.1080/23265507 .2017 .1339572

Grasha, A. F. (1994). A matter of style: The teacher as expert, formal authority, personal model, facilitator, and delegator. College Teaching, 42(4), 142-149.

Grasha, A. F. (1996). Teaching with style: The integration of teaching and learning styles in the classroom. Essays on Teaching Excellence, 7(5), 1995-96.

Hill, F., Tomkinson, B., Hiley, A., \& Dobson, H. (2016). Learning style preferences: An examination of differences amongst students with different disciplinary backgrounds. Innovations in Education and Teaching International, 53(2), 122-134. doi:https://doi.org/10.1080/14703297.2014.961504

Khandaghi, M. A., \& Farasat, M. (2011). The effect of teacher's teaching style on students' adjustment. Procedia-Social and Behavioral Sciences, 15(3), 1391-1394. doi:https://doi.org/10.1016/j.sbspro.2011.03.299

Koko, M., \& Nwiyi, G. (2007). Refocusing teacher education in Nigeria: Challenges and innovations. A Multidisciplinary Journal for National Association for the Advancement of Knowledge, 15, 12-15.

Nasibi, W. M., \& Kiio, M. (2005). History and government: Handbook for teachers. Nairobi, Kenya: Nehema Publishers.

Sarabdeen, J. (2013). Learning styles and training methods. New York, NY: Willey and John Son's.

Sosu, E. S. (2016). Analysis of preferred teaching styles used by history tutors. International Journal of Humanities and Social Sciences, 7(1), 34-40.

Sternberg, R. J., \& Wagner, R. K. (1991). MSG thinking styles inventory: Manual. New Haven, CT: Star Mountain Projects.

Sternberg, R. J., \& Zhang, L.-F. (2005). Styles of thinking as a basis of differentiated instruction. Theory into Practice, 44(3), 245-253. doi:https://doi.org/10.1207/s15430421tip4403_9

Suwanwong, A. (2017). Proactive professional networking strategies for enhancing teacher engagement in private school: Case study of Kraiumnuayvittaya army sponsor school. Journal of Advanced Research in Social Sciences and Humanities, 2(2), 96-102. doi:https://doi.org/10.26500/jarssh-02-2017-0203

Topçu, E. (2017). How do the teachers define social studies course? Journal of Education and e-Learning Research, 4(4), 139-153. doi:https://doi.org/10.20448/journal.509.2017.44.139.153 